\title{
Plutonium Wastes from the U.S. Nuclear Weapons Complex
}

\section{Robert Alvarez}

Senior Scholar, Institute for Policy Studies, Washington, D.C., USA

The amount of plutonium discarded as wastes from the U.S. nuclear weapons complex appears to be significantly greater than the U.S. Department of Energy's 1996 declaration of its plutonium holdings. This is due to in part to improved radioactive waste characterization and the disposal of plutonium residues originally intended for use in weapons. The Hanford site in Washington State has the largest quantity of plutonium wastes, which pose potentially serious human risks to ground water and the near shore the Columbia River. The department should revise its accounting for plutonium, and take steps to remove plutonium discarded to the environment at Hanford, as it is required to do at Idaho National Laboratory.

In 1996, Department of Energy (DOE) estimated that the United States produced and acquired 111.4 tons of plutonium. DOE reported that 12 tons of this plutonium was no longer available for use, including an estimated 3.4 tons lost to waste. ${ }^{1}$ The "inventory difference" between the book inventory, based on the DOE's records and estimates of production, acquisitions and removals, and the measured quantity in the physical inventory, was 2.8 tons, i.e., 2.8 tons of the plutonium produced was not accounted for. ${ }^{2}$

Based on more recent waste characterization data, ${ }^{3}$ approximately 12.7 tons-more than 10 percent of the total amount of plutonium-239 produced and acquired-is now estimated to have gone into waste streams. Five DOE sites are responsible for about 99 percent of these wastes (Figures 1 and 2).

Of the 12.7 tons (Table 1 ), about:

- 2.7 tons are in high-level radioactive wastes stored as liquids in tanks or granulated material in bins on the sites of former U.S. military reprocessing plants;

Received 11 December 2009; accepted 27 July 2010.

Address correspondence to Robert Alvarez, Senior Scholar, Institute for Policy Studies, Washington, D.C., USA. E-mail: bob@ips-dc.org 


\section{Alvarez}

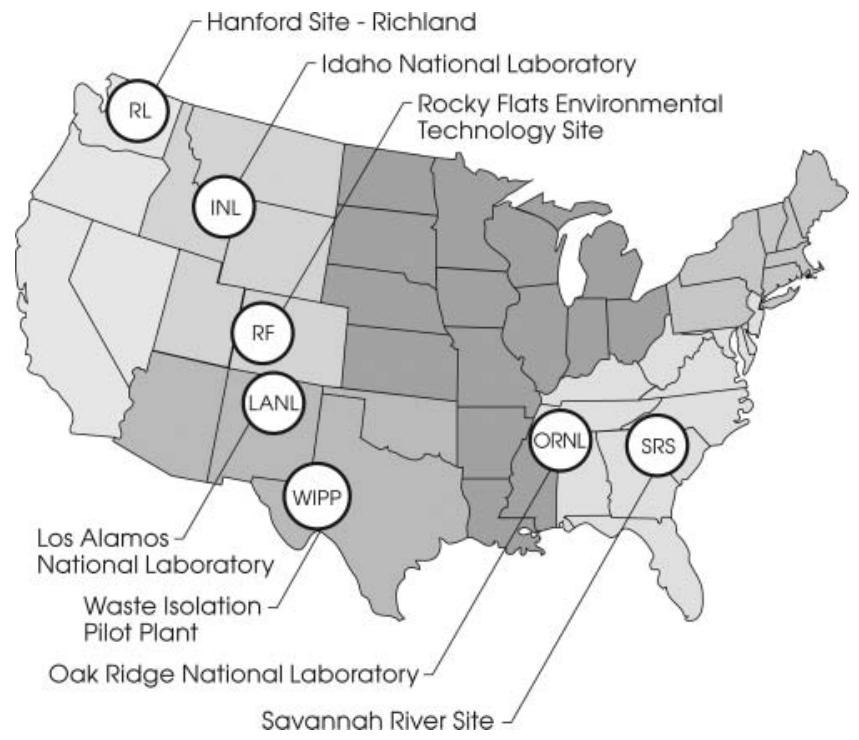

Figure 1: Large-quantity transuranic waste sites in the United States. The U.S. Department of Energy defines "large quantity sites" as having TRU waste volumes in excess of 14,000 cubic meters. Source: DOE/TRU-09-3425, Revision 0.

- 7.9 tons are in solid waste, which DOE is in the process of disposing in the Waste Isolation Pilot Project (WIPP), a geological repository in New Mexico for transuranic (TRU) wastes; and

- 2.1 tons are in solid and liquid wastes buried in soil prior to 1970 or held up in facilities at several DOE sites. DOE considers most of this plutonium to be permanently disposed.

The dramatic increase from the DOE's 1996 waste estimate is due to:

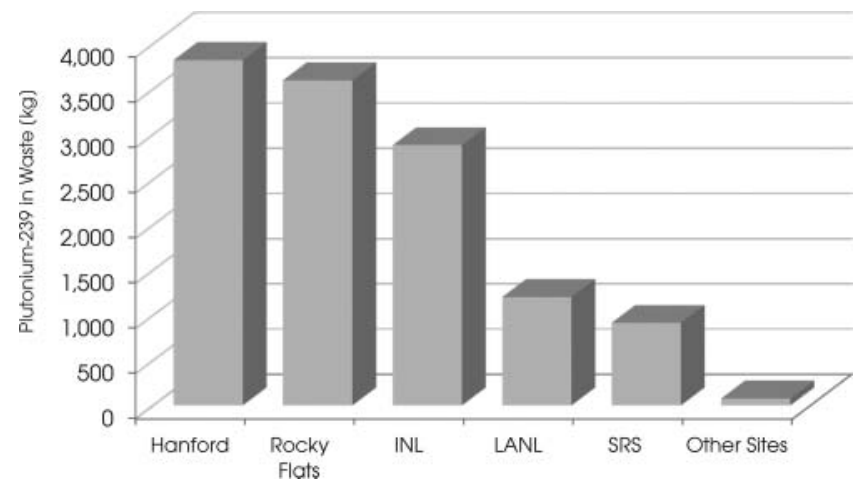

Figure 2: Plutonium-239 in wastes at DOE Sites (from Table 1). 
1. Reclassification as waste of more than 3.7 tons of plutonium in process residues at Rocky Flats and Hanford originally set aside for plutonium recovery for weapons; and

2. Improvements in waste characterization data.

The Hanford site in Washington State is responsible for nearly a third of DOE's plutonium wastes (4 tons)—more than any site in the U.S. nuclear weapons complex.

\section{ACCOUNTING FOR PLUTONIUM IN WASTE}

Plutonium-bearing waste is produced at reprocessing plants and where plutonium is fabricated into weapon components and fuel. Plutonium is a "transuranic" element because it is heavier than uranium. TRU waste is defined by the U.S. Environmental Protection Agency (EPA) as having a concentration greater than 100 nanoCuries per gram of alpha-emitting isotopes with half-lives greater than 20 years (EPA, 40 CFR 91). For plutonium-239, the transuranic that dominates in DOE TRU waste, 100 nanoCuries/gm translates into 1.6 milligrams of plutonium-239 per $\mathrm{kg}$ of waste.

Prior to the early 1970s, TRU wastes were disposed as low-level radioactive wastes directly into the ground. In 1970, however, the U.S. Atomic Energy Commission (DOE's predecessor agency) decided to require disposal of TRU wastes in a geologic repository designed to contain them for at least 10,000 years. Since 1970, pending deep disposal, U.S. TRU wastes have been stored in retrievable interim-storage containers.

Plutonium-239 is of greatest concern because of its higher concentration and long half-life of 24,100 years. With a specific activity about 200,000 times greater than uranium, plutonium-239 emits alpha particles as its principal form of radiation. Over time, americium-241, a decay product of 14-year halflife plutonium-241, builds up and increases the hazardous external penetrating gamma-ray radiation from TRU waste.

Alpha particles lose energy quickly within living tissue and create a dense trail of broken molecules. Particles less than a few microns in diameter can penetrate deep in the lungs and lymph nodes, and also can be deposited from the bloodstream in the liver, bone surface, and other organs. High doses from inhalation of TRU can cause lung damage, fibrosis, and even death. Tens of micrograms if inhaled can lead to cancer. ${ }^{4}$ Over the past several years, a significantly raised incidence of cancer has been reported among workers following exposure to plutonium. ${ }^{5}$

The behavior of plutonium in the environment depends upon its chemical form. It has been found to migrate at greater distances than assumed. ${ }^{6}$ As noted by S.S. Hecker, former Director of Los Alamos National Laboratory, 
Table 1: Plutonium in waste $(\mathrm{kg})$.

\begin{tabular}{|c|c|c|c|}
\hline Site & Description & DOE-1996 & $\begin{array}{l}\text { DOE waste } \\
\text { data }\end{array}$ \\
\hline Rocky Flats & Solid waste (now in WIPP) & 47 & $3,783^{b}$ \\
\hline Hanford & High-level waste & 455 & $1,115^{c}$ \\
\hline Hanford & Solid waste (WIPP bound) & 875 & $1,965^{\mathrm{b}}$ \\
\hline Hanford & Buried solid waste & - & $452^{d, e}$ \\
\hline Hanford & Buried liquid waste & 92 & $205^{f}$ \\
\hline Hanford & $\begin{array}{l}\text { Liquid waste in facilities and } \\
\text { holding tanks }\end{array}$ & - & $264^{f}$ \\
\hline $\begin{array}{l}\text { Los Alamos National } \\
\text { Laboratory }\end{array}$ & Solid waste (WIPP bound) & 610 & $791^{\mathrm{b}}$ \\
\hline $\begin{array}{l}\text { Los Alamos National } \\
\text { Laboratory }\end{array}$ & Buried waste & - & $50 \mathrm{~g}, \mathrm{~h}$ \\
\hline Idaho National Laboratory & Solid wastes (WIPP bound) & 1,106 & $1,062^{b}$ \\
\hline Idaho National Laboratory & $\begin{array}{l}\text { Pre-1970 solid waste (WIPP } \\
\text { bound) }\end{array}$ & - & $1,078^{i}$ \\
\hline Idaho National Laboratory & Calcined High-level waste & 72 & $771^{j}$ \\
\hline Idaho National Laboratory & $\begin{array}{l}\text { Solutions stored in tank } \\
\text { farms }\end{array}$ & 8 & $8^{a}$ \\
\hline Savannah River Site & High-level waste & 575 & $847^{k}$ \\
\hline Savannah River Site & Solid waste (WIPP bound) & 193 & $193^{b}$ \\
\hline Savannah River Site & Buried waste & - & $25^{\prime}$ \\
\hline Other DOE sites & Solid waste (WIPP bound) & 59 & $82^{\mathrm{b}}$ \\
\hline Other DOE sites & Buried waste & - & $27^{\mathrm{m}}$ \\
\hline Total & & 3,919 & 12,717 \\
\hline
\end{tabular}

\footnotetext{
aU.S. Department of Energy, "Plutonium: The First 50 Years," op. cit.

bU.S. Department of Energy, "Annual Transuranic Waste Inventory Report-2009," op. cit.

CU.S. Department of Energy, "Tank Waste Inventory Network System, Best Basis Estimate," op. cit

dW.O. Greenhalgh, "Pre 1970 Transuranic Solid Waste at Hanford," Westinghouse Hanford Company, WHC-SD-WM-ES-325, 1995.

eWashington State, Department of Health, "Final Environmental Impact Statement, Commercial Low-Level Radioactive Waste Disposal Site Richland, Washington," Vol. 1, DOH Publication 320-031, May 2004.

fU.S. Department of Energy, "Draft Tank Closure and Waste Management Environmental Impact Statement for the Hanford Site, Richland, Washington," DOE/EIS-0391, October, 2009, Appendix S.

SU.S. Department of Energy, "Summary Data on the Radioactive Waste, Spent Nuclear Fuel, and Contaminated Media Managed by the U.S. Department of Energy," DOE/EM-00-0384, 2000.

hU.S. Department of Energy, Office of Environmental Management, Memo from Richard J. Guimond regarding Plutonium in Waste Inventories, January 30, 1996.

T.A. Batcheller, ef al, "Colloidal Plutonium at the OU 7-13/14 Subsurface Disposal Area: Estimate of Inventory and Transport Properties," Bechtel BWTX Idaho LLC, IC P/EXT-04-00253, May 2004.

iU.S. Department of Energy, "Idaho High-Level Waste and Facilities Disposition, Final Environmental Impact Statement," DOE/EIS-0287, Appendix C-7, Table C.7.

kU.S. Department of Energy,"SRS High-Level Waste Tank Data," 1999.

IU.S. Department of Energy, "Workplan/RCRA Facility Investigation/Remedial Investigation Report for the Old Radioactive Waste Burial Ground 643-E, S01-S22," Volume I-Text and Vol. II-Appendices, WSRC-RP-97-00127, August 2000.

mJ.R. Trabalka, "Buried Transuranic Wastes at ORNL: Review of Past Estimates and Reconciliation with Current Data," ORNL RM- 13487, 1997; J.R. Cochran et al., "Intermediate Depth Burial of Classified Transuranic Wastes, Arid Alluvium", LA-UR-99-639, April 1999; G. Shott et al., "Special Analysis of Transuranic Waste in Trench TO4C at the Area 5 Radioactive Waste Management Site, Nevada Test Site, Nye County, Nevada," DOE/NV/25946-47, May 2008.
} 
this behavior is "one of the most challenging applications of modern chemistry because of the inherent complexity of plutonium and the corresponding complexity of the natural environment."7

In 1980, the U.S. Congress authorized the design and construction of the deep-underground WIPP near Carlsbad, New Mexico for TRU waste generated for military purposes. ${ }^{8}$ A bedded salt formation was chosen because of its long-term stability and self-sealing properties. The WIPP facility is located 660 meters underground and has an authorized disposal capacity of 175,000 cubic meters. Based on recent waste characterization data, DOE estimates that 83,050 cubic meters of TRU wastes containing 7.9 tons of plutonium will be disposed in WIPP. About half of this plutonium has already been emplaced. ${ }^{9}$

\section{Reclassification}

During the Cold War residual plutonium from production processes were stored and recovered if the cost was less than making new plutonium in production reactors. After the downsizing of its Cold War warhead stockpile, DOE no longer needed these residues and reclassified them as waste. About 3.5 tons of plutonium in residues from DOE's Rocky Flats plant have been disposed at WIPP. ${ }^{10}$ At Hanford, 0.2 tons of plutonium in residues, originally set aside for recovery for weapons, is also bound for disposal at WIPP. ${ }^{11}$ Additional amounts of plutonium originally set aside for weapons at the Savannah River Site, Hanford, and Los Alamos have also been reclassified as waste. ${ }^{12}$

\section{Better Waste Characterization}

Prior to 1970, when most of U.S. plutonium production occurred, material measurement technologies "were less accurate than today." ${ }^{13}$ In recent years, environmental compliance agreements with host states have resulted in more rigorous measurements of plutonium in wastes, which, in some cases, has resulted in dramatic increases. The amount of plutonium in Hanford high-level radioactive waste tanks, for example, has been found to be more than twice the amount estimated in $1996 .{ }^{14}$

Indeed, the remeasurements at Hanford may require an increase in the estimates of the original amount of plutonium produced there. According to a 2001 study of nuclear material flow and accounting at Hanford:"The quantities of NM [nuclear material] removed from the inventory as NOL [normal operating losses] do not agree with the quantities of NM classified as waste in the waste management inventory of waste ... Significantly more NM was produced in the reactors but not recovered in the separation facilities and was discharged along with fission waste."15 


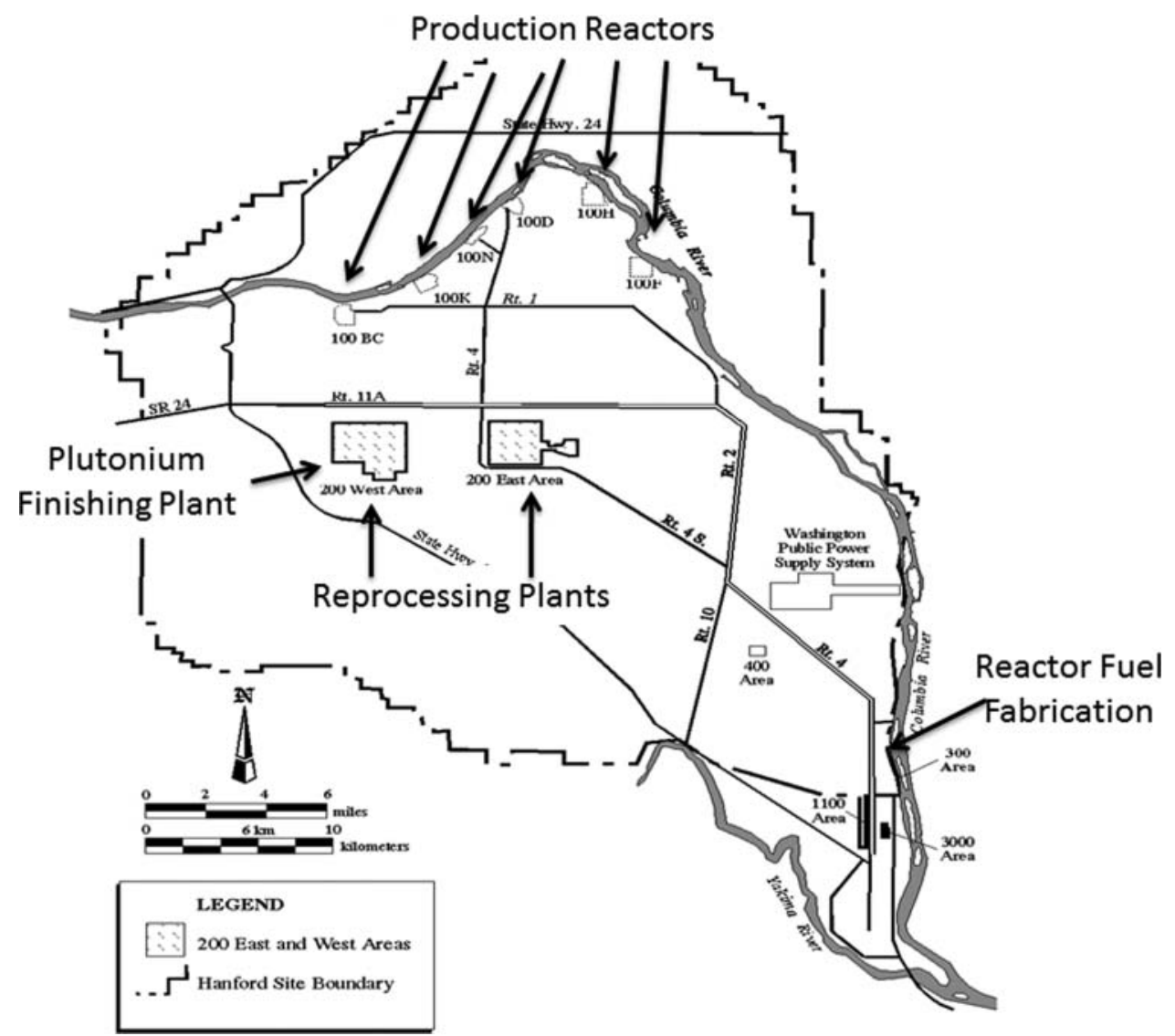

Figure 3: Plutonium Production at Hanford.Source: Adapted by author from DOE/ EIS-0189, 1996, Fig. B.1.1.1.

\section{Plutonium Wastes at Hanford}

At the Hanford site, natural (0.71 percent uranium-235) or slightly enriched uranium (primarily 0.95 and 1.25 percent uranium-235) metal was clad with aluminum to make fuel for the production reactors (Figure 3). Irradiated fuel was discharged into basins of water to allow for cooling and decay of shortlived radionuclides before being sent for chemical separation of plutonium and uranium. Irradiated fuel ruptures and corrosion led to residual plutonium in storage basins and contamination of the nearby environment. ${ }^{16}$

Plutonium was extracted from about 99,000 metric tons uranium (MTU) of spent fuel in four chemical separations plants that operated during overlapping periods. ${ }^{17}$ Additional amounts of plutonium came from offsite processing facilities and foreign sources. ${ }^{18}$ About 70 percent of the irradiated fuel was processed at the Plutonium Uranium Extraction Plant (PUREX), whose chemical process was subsequently used in reprocessing plants all over the world. After chemical separation, liquid reprocessing waste containing residual amounts 
of plutonium and other TRU were mostly transferred to high-level radioactive waste tanks. Liquid waste containing plutonium also was discharged into cribs, trenches, and ponds. ${ }^{19}$

Beginning in 1949, separated plutonium nitrate from the reprocessing plants was sent to the Hanford Plutonium Finishing Plant (PFP), where plutonium was purified into metal and oxides. ${ }^{20}$ Liquid wastes were discharged into unlined soil disposal sites until 1973, after which they were sent via a transfer line to high-level waste tanks. ${ }^{21}$ About 86 percent of Hanford's plutoniumcontaining liquid waste discharges occurred in the PFP zone. ${ }^{22}$

According to DOE's 1996 plutonium declaration, about 2 percent of the total plutonium produced at Hanford went into waste (1.1 tons). ${ }^{23}$ More recent waste characterization data indicates about 6 percent of the plutonium produced at Hanford went into waste (4 tons) - more than any other DOE site.

Of this amount, about 2.7 tons of plutonium in liquid and solid wastes were mostly discharged, or buried in soil; 1.1 tons of residual plutonium-mostly from reprocessing plants-were discharged into the high-level radioactive waste tanks $;{ }^{24}$ and an estimated $264 \mathrm{~kg}$ are held up in laboratories, reprocessing plants and holding tanks. DOE plans to convert the plutonium-containing high-level radioactive waste into glass logs for geological disposal.

Prior to 1970, about 371 kilograms of plutonium in solid wastes was dumped into containers such as cardboard boxes. The cardboard boxes were then dumped into unlined trenches mostly associated with the PFP. ${ }^{25}$ Between the mid-1960s and 1980, about $100 \mathrm{~kg}$ of plutonium was disposed in a similar fashion in a commercial radioactive waste landfill located in the Hanford 200-East area. ${ }^{26}$

Production records at Hanford appear to understate plutonium losses. As researchers noted in 2001, "The ability to measure the plutonium content of waste streams was vastly inferior compared to the ability to measure plutonium in the primary feed and product streams." ${ }^{27} \mathrm{~A}$ case in point is 216-Z-9 Crib, a soil disposal site roughly 10 meters by 20 meters in area, which operated from 1955 to 1962, receiving wastes from the RECUPLEX facility, a scrap recovery operation in the PFP zone, which discharged approximately 1 million gallons of plutonium-bearing wastes. ${ }^{28}$ Although processing records indicated that approximately $27 \mathrm{~kg}$ were discarded into the crib, samples taken in the years following closure of the 216-Z-9 Crib indicated that it may have contained as much as $150 \mathrm{~kg}$ of plutonium, with soil concentrations as high as 34.5 grams per liter. ${ }^{29}$ This was enough so that water intrusion could possibly have set off a nuclear criticality event that could have resulted in near-lethal doses to workers..$^{30}$ By the late 1970s, $58 \mathrm{~kg}$ of plutonium had been removed from the top 30 centimeters of soil using remotely controlled equipment. ${ }^{31}$

About 2 tons of the plutonium buried on the Hanford site is planned for disposal in WIPP. ${ }^{32}$ The remaining 0.7 tons was buried prior to $1970 .{ }^{33}$ According to the Government Accountability Office, "DOE has long considered pre-1970s 


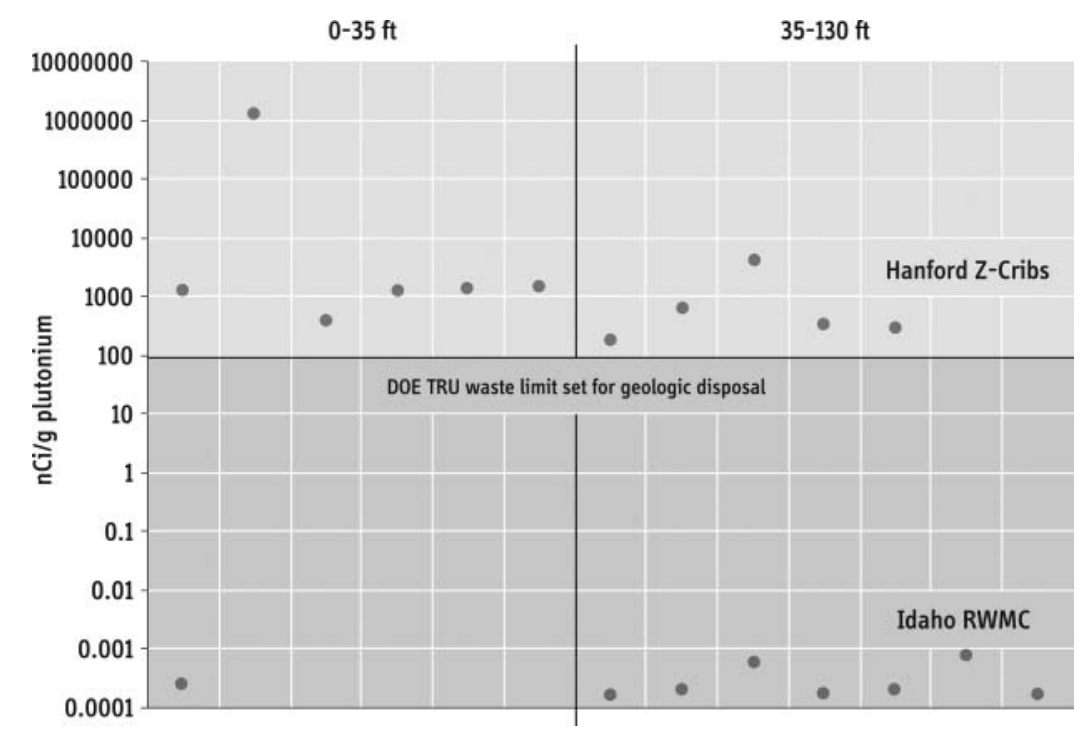

Figure 4: Subsurface Contamination at the DOE's Hanford and Idaho Sites. The contamination level at the Hanford Z-Cribs is above the DOE's threshold for removal to the WIPP repository down to a depth of 130 feet (about 40 meters).Source: USDOE/INEL, EGG-ER-10546, Rev. 3 (March 1994).

buried wastes permanently disposed."34 DOE officials view long-term stewardship efforts, which are likely to rely heavily on land control, site surveillance, monitoring, maintenance, record keeping, and related activities, as inherently low cost. Federal institutional controls, however, require that disposal of radioactive wastes at DOE sites must pose less than a 1 in 10,000 chance of exceeding EPA drinking water standards over a 10,000 year time frame. ${ }^{35}$

In 2000, the National Academy of Science challenged the DOE's approach and concluded that: "Institutional controls will fail [emphasis added]. Past experience with such measures suggests, however, that failures are likely to occur, possibly in the near term, and that humans and environmental resources will be put at risk as a result."36

A recent estimate by the DOE underscores the Academy's concern and finds that plutonium in groundwater from dump sites at Hanford could reach the near shore of the Columbia River in less than 1,000 years at concentrations 283 times greater than the federal drinking water standard. ${ }^{37}$

Migration beneath Hanford disposal sites has been enhanced by solvents, acids, and concentrated salts. ${ }^{38}$ Based on borehole measurements, plutonium contamination at Hanford is relatively uniform with depth and exceeds the $100 \mathrm{nCi} / \mathrm{g}$ limit required for removal and geological disposal down to depths greater than 100 feet (30 meters). Deep contamination of the unsaturated soil (vadose zone) at Hanford appears to be orders of magnitude greater than at DOE's Idaho site, which has a greater concentration of buried pre-1970 TRU wastes (Figure 4). ${ }^{39}$ 


\section{Plutonium Wastes at the Idaho National Laboratory (INL)}

INL is estimated to have buried about 1.1 tons of plutonium-239 before $1970 .{ }^{40}$ Beginning in 1954, plutonium-contaminated wastes from the DOE's Rocky Flats plant, which made plutonium weapons components, were disposed at INL. After a major fire in August 1969 at Rocky Flats resulted in burial of an unprecedented amount of plutonium-239 in Idaho. ${ }^{41}$ The state resisted further disposal and demanded removal of these wastes from the site. Idaho's opposition contributed to DOE's decision to establish the WIPP repository and to require that TRU wastes generated after 1970 to be retrievably stored. In 1995, Idaho entered into an agreement with DOE and the EPA that required the removal of high-level radioactive wastes, spent reactor fuel and TRU wastes from the state by 2035 . Until the Federal District Court in Idaho ruled in favor of the state in 2008, however, DOE refused to remove TRU wastes buried at INL prior to $1970 .^{42}$

\section{SUMMARY}

The U.S. Department of Energy's 1996 report, "Plutonium: The First 50 Years," showed a difference between the book inventory based on records and estimates of plutonium production, acquisitions, and removals compared to the measured quantities in stocks of 2.8 tons-that is, 2.8 tons were not accounted for. With the new and revised waste data, most or all of this inventory difference will be removed. Depending upon how much of the increase in waste is due to reclassification and how much due to improvements in waste characterization data, estimates of plutonium production might have to be raised slightly from the 1996 figure.

DOE is responsible for the Nuclear Materials Management and Safeguards System (NMMSS), the U.S. government's information system containing current and historic data on the possession, use and shipment of nuclear materials. The recent radiological waste characterization data has not been incorporated in NNMMS system, however, because data on plutonium in material declared to be waste are not systematically updated. This creates significant accountability problems at both the national and international levels. Fortunately, DOE has decided to update its 1996 declaration to reflect improved data on the quantities of plutonium in waste. This will reduce uncertainties in historical plutonium production and provide additional quality assurance for waste data.

Despite evidence of significant deep subsurface migration, DOE currently plans to leave about 0.7 MT of plutonium disposed before 1970 behind in the ground at the conclusion of its environmental cleanup at Hanford. DOE should, however, remove as much buried plutonium as possible at Hanford for geologic disposal, as it is doing at the Idaho National Laboratory. 
Although International Atomic Energy Agency (IAEA) monitoring of wastes already emplaced at WIPP may be impractical, it is worth exploring whether future waste shipments to WIPP should be monitored by the IAEA and the declared plutonium content in the wastes checked to provide a basis for international confidence in U.S. declarations of its plutonium disposition and to provide a template for the disposition of plutonium-bearing wastes in other countries.

\section{NOTES AND REFERENCES}

1. U.S. Department of Energy, "Plutonium: The First 50 Years," DOE/DP-0137, Figures 12, 14 (February 1996), 77-82, <http://www.ipfmlibrary.org/doe96a.pdf $>$. The 3.4 tons are identified as normal operating losses (NOL). Table 16, based on extrapolations of direct measurement of the wastes indicated a waste amount of 3.9 tons (see Table 1 of this article). The 0.5 ton difference is attributed to two primary causes as explained in the DOE report. One, waste inventories are tracked for environmental, safety, and health reasons, and are therefore not necessarily calculated like normal operating losses. Two, the direct waste calculation includes off-site sources, while the normal operating losses include only waste generated from government on-site production.

2. U.S. Department of Energy, "Plutonium: The First 50 Years," op. cit., Figures 1, 3.

3. See notes to Table 1 and endnote references below for information on the specific sites of TRU wastes.

4. National Research Council, Management and Disposition of Excess Plutonium (Washington, D.C: National Academy Press, 1995), 333, <http://www.nap.edu/catalog. php?record_id $=2345 \#$ toc $>$.

5. Agency for Toxic Disease Registry, Department of Health and Human Services, "Toxicological Profile for Plutonium," September 2007, <http://www.atsdr.cdc.gov/ tfacts143.pdf $>$.

6. A.B. Kerstin, D.W. Feud, D.L. Finnegan, D.J. Rook, D.K. Smith \& J.L. Thompson, "Migration of Plutonium in Ground Water at the Nevada Test Site," Nature 397 (7 January 1999): pp. 56-59.

7. S.S. Hecker, "Plutonium Science Challenges Future Researchers," Actinide Research Quarterly, 2nd/3rd Quarter, (2000), <http://www.lanl.gov/source/orgs/nmt/ nmtdo/AQarchive/00fall/editorial.html > .

8. U.S. Department of Energy, National Security and Military Applications of Nuclear Energy Authorization Act of 1980, Public Law, 96-164.

9. U.S. Department of Energy, Carlsbad Field Office, "Annual Transuranic Waste Inventory Report-2009," DOE/TRU-09-3425 Rev. 0 (2009), Tables 3-1, 3-2, 3-11 and 12, <http://cid.em.doe.gov/pdfs/Annual_TRU_Waste_Inventory_Report-2009_ DOE_TRU-2009-3425.pdf $>$.

10. U.S. Department of Energy, "Record of Decision on Management of Certain Plutonium Residues and Scrub Alloy Stored at the Rocky Flats Environmental Technology Site," Federal Register Vol. 63, No. 230, (1 December 1998); "Supplemental Analysis for the Disposal of Certain Rocky Flats Plutonium-Bearing Materials at the Waste Isolation Pilot Plant," DOE/EIS-0026-SA-3 (November 2002), <http://www.wipp.energy. gov/Documents_All_Title.htm>; and "Management of Certain Plutonium Residues and Scrub Alloy Stored at the Rocky Flats Environmental Technology Site," Federal 
Register Vol. 66, No. 12, (18 January 2001), <http://nepa.energy.gov/nepa_documents/ rods/2001/4803.pdf $>$.

11. D.C. Lini and L.H. Rodgers, "Plutonium Finishing Plant-Plutonium and Uranium Oxide. Characterization of Items with Less than 30 Weight Percent Plutonium," HNF-10919, Rev. 0 (March 2002), <http://www.osti.gov/energycitations/product.biblio. jsp?query_id $=3 \&$ page $=0 \&$ osti_id $=808358>$.

12. Mathew McCormick, Manager, DOE Richland Operations Office, in discussion with the author, 29 July 2010.

13. U.S. Department of Energy, "Plutonium: The First 50 Years: United States Plutonium Production, Acquisition and Utilization from 1944 through 1994," DOE/DP-0137 (1996), p. 53, <www.ipfmlibrary.org/doe96.pdf > .

14. U.S. Department of Energy, "Tank Waste Inventory Network System, Best Basis Estimate," Fluor Hanford Corp., 090803, (September 2003).

15. U.S. Department of Energy, "Nuclear Material Mass Flow and Accountability on the Hanford Site," Fluor Hanford Corp., HNF-8069 (October 2001), pp. 3-7, $<$ http://www5.hanford.gov/pdwdocs/fsd0001/osti/2001/I0035319.pdf>.

16. G.B. Malinger, C.H. Deluged, M.A. Gerber, B.N. Nat, A.J. Schmidt, and T.L. Walton, "Disposition Options for Hanford Site K-Basin Spent Nuclear Fuel Sludge," PNNL14729 (January 2004), <http://www.pnl.gov/main/publications/external/technical_ reports/PNNL-14729.pdf>; P.C. Jerman, W.N. Koop, and F. E. Owen, "Release of Radioactivity to the Columbia River from Irradiated Fuel Element Ruptures," Hanford Atomics Production Operation, RL-REA-2160 (May 1965), <http://www5.hanford. gov/ddrs/common/findpage.cfm?AKey=D9042989 > ; R.E. Peterson, "K Basins Groundwater Monitoring Task, Spent Nuclear Fuels Project: Report for April, May, and June 2006," PNNL-16001 (August 2006), <http://www.pnl.gov/main/publications/external/ technical_reports/PNNL-16001.pdf $>$.

17. U.S. Department of Energy, "Nuclear Material Mass Flow and accountability on the Hanford Site", op. cit., pp. 2-3.

18. Ibid., p. 2.4 .

19. Ibid., p. 4.4 .

20. Ibid. pp. 4-5.

21. Ibid., pp. 4-6.

22. U.S. Department of Energy, CH2MHILL, Hanford Soil Inventory Model Data (SIM 2005), PFP, WTP-ETF-A-C- Farm, Unassigned 200 Areas 1 and 2, U Plant, T-Plant, TFarm, S U Farm, Semi-Works, Redox, PUREX, 200E Ponds, 200 W ponds, B-Pant, WM, NRDWL-BC-Control, and PFP zones, 2005, PFP Zone, 2005.

23. "Plutonium: The First 50 Years," p. 56.

24. U.S. Department of Energy, "Tank Waste Inventory Network System, Best Basis Estimate," op. cit.

25. W. O. Greenhalgh, "Pre-1970Transuranic Solid Waste at Hanford," Westinghouse Hanford Company, WHC-SD-WM-ES-325, 1995, Table 4.1, p. 4.1.

26. Washington State, Department of Health, "Final Environmental Impact Statement, Commercial Low-Level Radioactive Waste Disposal Site, Richland, Washington," Vol. 1, DOH Publication 320-031, Table D. (May 2004), pp. 55-56, <http://www.doh.wa. gov/ehp/rp/waste/vol1.pdf $>$. 
27. "Nuclear Material Mass Flow and Accountability on the Hanford Site," op. cit., pp. $4-6$.

28. K.R. Ridgeway, M.D. Veatch, D.T. Crawley, and Victor I. Sviridov, "216-Z9 Crib History and Safety Analysis," Atlantic Richfield Hanford Company, ARH2207 (November 1971), p. 1, <http://www5.hanford.gov/ddrs/common/findpage.cfm? AKey=D8639356ARH-2207 > . Note on web site: D8639356ARH-2207

29. S.L. Charboneau, A. Hopkins, C.S. Sutter, and J.A. Teal, "Decommissioning the 216-Z-9 Crib Plutonium Mining Facility at the Plutonium Finishing Plant: Issues Characterization," Fluor Hanford Co, HNF-304575-FP, Rev.0 (2007), 1, <http://www. osti.gov/bridge/servlets/purl/908812-OJpjiK/>.

30. M.C. Jacobs and D.L. Uebelacker, "Radioactive Contamination in Liquid Wastes Discharged to Ground within the Chemical Separations Area Control Zone Through 1969," Atlantic Richfield Hanford Co., ARH-1608 (March 1970), p. 21 <http://www5. hanford.gov/ddrs/common/findpage.cfm?AKey=D8603996> .

31. "Decommissioning the 216-Z-9 Crib Plutonium Mining Facility," op. cit.

32. U.S. Department of Energy, "Annual Transuranic Waste Inventory Report-2009," op. cit., Tables 3-11, 3-12.

33. Ridgeway et al., "216-Z-9 Crib History and Safety Analysis," op. cit. and, "Pre 1970 Transuranic Solid Waste at Hanford," op. cit.

34. United States Government Accountability Office, Report to the Subcommittee on Energy and Water Development, Committee on Appropriations, House of Representatives, "Nuclear Waste, Plans for Addressing Most Buried Transuranic Wastes Are Not Final, and Preliminary Cost Estimates Will Likely Increase," GAO-07-761 (June 2007) $<$ http://www.gao.gov/new.items/d07761.pdf $>$.

35. U.S. Department of Energy, Nuclear Regulatory Commission and Environmental Protection Agency, The Interagency Steering Committee on Radiation Standards, "Federal Institutional Control Requirements for Radioactive Waste and Restricted Release of Property Containing Radioactive Material" (undated) <http://www.hss.energy. gov/nuclearsafety/env/guidance/aea/radtabls.pdf > .

36. Committee on Remediation of Buried and Tanks Wastes, Board on Radioactive Waste Management, National Research Council, Long-Term Institutional Management of U.S. Department of Energy Legacy Waste Sites, (Washington, D.C: National Academy Press, 2000) <http://www.nap.edu/catalog.php?record_id=9949\#toc $>$.

37. U.S. Department of Energy, "Draft Tank Closure and Waste Management Environmental Impact Statement for the Hanford Site, Richland, Washington," DOE/EIS0391, October, Appendix U, Table U-2<http://nepa.energy.gov/documents/EIS-0391_DAppendixU.pdf $>$.

38. U.S. Department of Energy, "Draft Tank Closure and Waste Management Environmental Impact Statement for the Hanford Site," Richland, Washington, DOE/EIS-039 (October 2009), <http://nepa.energy.gov/1148.htm > Appendix U, Table U-2>.

39. U.S. Department of Energy, Idaho National Engineering Laboratory, Dames and Moore, "Compilation and Summarization of the Subsurface Disposal Area Radionuclide Transport Data at the Radioactive Waste Management Complex," EGGER-10546, Rev. 3 (March 1994), <http://ar.inel.gov/owa/getgif_2?F_DOC=EGG-ER10546\&F_REV $=03 \& F \_P A G E=1 \& F \_G O T O=1>$; U.S. Department of Energy, Office of Environmental Management, Stoller Hanford Co, "Borehole Logging Reports," DOEEM/GJ922-2005 (2005).

40. T.A. Batcheller, G.D. Redden, "Colloidal Plutonium at the OU 7-13/14 Subsurface Disposal Area: Estimate of Inventory and Transport Properties," Bechtel 
BWTX Idaho LLC, IC P/EXT-04-00253 (May 2004), <http://ar.inel.gov/images/pdf/ 200405/2004051900569GSJ.pdf $>$; and U.S. Department of Energy, "Annual Transuranic Waste Inventory Report-2009," op. cit., pp. 144-147. According to the latter report, three waste streams of pre-1970 TRU with a total volume of 8,470 cubic meters, containing 4,800 $\mathrm{Ci}$ of plutonium-239 and $1080 \mathrm{Ci}$ of Plutonium-240 (77 $\mathrm{kg}$ and $4.6 \mathrm{~kg}$ respectively) are currently planned for disposal in WIPP.

41. Batcheller, et al., "Colloidal Plutonium at the OU 7-13/14 Subsurface Disposal Area: Estimate of Inventory and Transport Properties," op. cit.

42. U.S. District Court for the District of Idaho, Agreement to Implement U.S. District Court Order Dated May, 25, 2006 (1 July 2008). 